\title{
活断層はどこから割れ始めるのか？
}

一活断層の分岐形態と破壊伝播方向一

$$
\begin{aligned}
& \text { 中田高* 島崎邦彦** } \\
& \text { 鈴木康弘 }{ }^{* * *} \text { 佃 栄 吉**** }
\end{aligned}
$$

\section{Fault Branching and Directivity of Rupture Propagation}

\author{
Takashi NAKATA*, Kunihiko SHIMAZAKI**, \\ Yasuhiro SUZUKI ${ }^{* * *}$ and Eikichi TSUKUDA $* * * *$
}

\begin{abstract}
This paper proposes a method to identify the directivity of rupture propagation based on the branching features of active fault traces.

Direction of ruptre propagation is closely related to strong ground motions and resulting earthquake damage. Therefore, predicting rupture directivity is crucial in predicting strong motions to mitigate earthquake damage. However, the directions of fault ruptures were ascertained only after earthquakes from the observed seismological records and not before the earthquakes.

We found an interdependent correlation between the branching direction of the surface ruptures and the direction of their propagation as shown in Fig. 1, from an investigation of recent earthquake fault ruptures such as the 1995 Northern Sakhalin earthquake, the 1995 Hyogoken-nambu earthquake, the 1992 Landers earthquake, the 1990 Luzon earthequake, the 1979 Imperial Valley earthequake, and the 1930 Kita-Izu earthequake. The branching of faults during rupture propagation is regarded as an effective energy dissipation process and could result in final rupture termination.
\end{abstract}

Because patterns of surface traces of active faults are the results of repeated earthquake faulting, the branching of active faults leads us to suggest that the direction of rupture propagation is also predictable before the active faults generate earthquakes in the future.

Several active faults with well-defined branching such as the active faults of the strike-slip type in the Kobe-Osaka area, those in California, and the active fault sysytem in the northern Luzon, Philippines are examined. Branching of the reverse faults in the foot-hills of Darjeeling Himalaya is also shown as an example of active faults of the dip-slip type. This

\footnotetext{
* 広島大学文学部地理学教室

** 東京大学地震研究所

*** 爱知県立大学情報科学部

**** 地質調査所

* Department of Geography, Hiroshima University

** Earthquake Research Institute, University of Tokyo

*** Aichi Prefectural University

**** Geological Survey of Japan
} 
test clearly shows that the direction of rupture propagation, and in some cases the epicenter location, can be deduced from the branching features on the basis of our proposed method.

Key words : fault-rupture propagation, fault branching, active fault, earthquake fault キーワード：断層破壊伝播, 断層分岐, 活断層, 地震断層

\section{I. はじめに}

筆者らは, 大地震の発生源となる活断層の断層 線の分岐形態から，断層の破壊伝播方向や破壊開 始点を予測する単純明快な手法を考案した。地震 時における断層の動的破壊過程は, 地震災害の主 原因となる強振動特性と密接に関連する。特に大 地震が発生した場合，断層の破壊伝播がどの方向 に進むかによって断層近傍地域の強振動特性（方 向効果: directivity effect）が大きく変わり, そ の結果生じる地震被害の大きさに強く影響を与え ることが知られている。このことは, 断層伝播方 向が地震動特性を予測したり, 地震災害の軽減の ために極めて重要な情報であることを示している。 しかしながら，断層破壊伝播方向は、これまで地 震記録などから地震後に明らかにされることはあっ ても，地震前に推定されることはなかった。

筆者らは, 過去の大地震に伴って地表に出現し た地震断層には, 断層の分岐方向と断層破壊の伝 播方向が一致する事例が多いことに着目する。こ のような破壊伝播過程において断層が分岐する現 象は, 理論的には地震エネルギーの効果的な散逸 過程の一つであり，これによって破壊伝播が終息 すると説明される。このため, 断層分岐方向と断 層破壊伝播過程には強い関連があると推定される。

本論文では，まず断層形態から破壊伝播方向を 推定するモデルを提示し, 歴史時代の大地震に伴っ て生じた日本国内や海外の地震断層の分岐形状と 破壊伝播方向を検討するとともに, 検討結果に基 づいて断層破壊開始地点の推定を行なう。さらに， 断層線の分岐が明瞭ないくつかの活断層を例に, 破壊伝播の方向や破壊開始点位置の推定を試みる。

\section{II. 断層の分岐と破壊伝播}

断層の幾何学的形態と断層破壊プロセスに関し て, 小出 (1983) は, 多重エシュロン断層系のギャッ プや屈曲などの幾何学的形態に注目し、これが断 層破壊プロセスを支配している可能性を指摘した。 一方, King (1986) やSibson（1987）は, 地震 断層の屈曲やステップ構造の詳細な解析をもとに, 断層の破壊プロセスでの幾何学構造の役割を議論 している。佃（1990）は, 同じ立場から形態的特 徵, 特にバリア（断層変位量分布の不連続部）に 注目し，いくつかの地震断層を具体的に検討した うえで, 断層の破壊は圧縮性バリアで始まり,引 張性バリアで終息することを述べている。佃 （1991）は, 地震断層との比較から活断層の幾何 学的バリアを認識し, 力学的性質を見極めること が活断層の破壊プロセスを考えるうえで重要であ り，断層の破壊の開始や終息位置が推定できる可 能性を述べているが，活断層線の形態から具体的 に圧縮性バリアを推定することはさほど容易では ない。

破壊現象がどのように発生したかを示す最も重 要な証拠物は「割れ目」(断層もこれと同義) で あり，その形状から，(A) 枝分かれしない割れ 目と（B）枝分かれする割れ目に分けられる（寺 尾，1968）。(B)は割れ目の成長過程で爆発的に 枝分かれを生じるもので，ガラスのようにもろい 物質の中で割れ目が急速に形成される場合にみら れる。このような割れ目は, 破壞の開始点から割 れ目が拡大していく過程で, 破壊伝播の進行方向 に向かって分岐し，伝播方向に向かって V 字状あ るいはY 字状の分岐形状を示すことになる。この ような特徵に注目すれば, 断層の形状と破壊伝播 方向との関係について次のようなモデルが提示さ れる(図1)。 
A-1

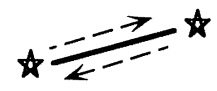

A-2

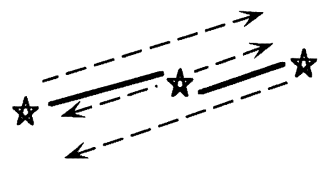

B-1

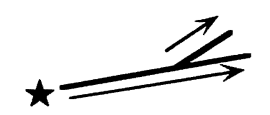

B-2

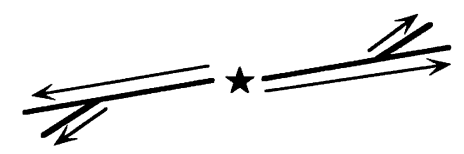

B-3

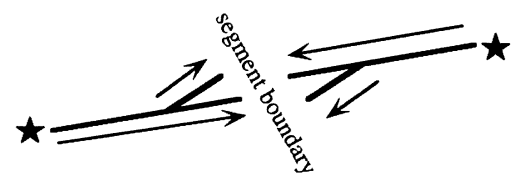

\begin{tabular}{|c|c|l|}
\hline Epicenter & Directivity & Predictability \\
\hline$\star$ & $-\longrightarrow \rightarrow$ & Unpredictable \\
\hline$\star$ & $\longrightarrow$ & Predictable \\
\hline
\end{tabular}

図 1 断層分岐と断層破壊伝播方向のモデル.

Fig. 1 A model for fault branching and rupture propagation.

断層が一本の断層線によって構成される場合 （図 1-A-1）は，破壊は断層線の一方の端からも う一方の端に向かって伝播すると予測されるが, どちらの端から破壊が開始するかを特定すること はできない。

断層が枝分かれしない複数の断層線によって構 成される場合（図 1-A-2）は，それぞれの断層線 の端が破壊開始点となる可能性があるため, 中間 の接合部から双方向（bilateral）に破壊が伝播す る場合と, 一方の終端から他方の終端へ一方向 （unilateral）に伝播する場合との三つのケースが 想定されるが，そのいずれかを特定することはで きない。

断層が枝分かれする断層線で構成される場合 （図 1-B-1）は，破壊は分岐しない断層線の端か ら始まり, 断層線の分岐方向に向かって破壊は伝
播すると考えることができる。

断層が枝分かれする複数の断層線で構成され， かつ互いに遠ざかる方向へ分岐する場合（図 1-B -2）は, 破壊は断層の中央に位置する断層線の接 合部から始まり，それぞれの分岐方向に向かって 双方向に伝播すると考えることができる。

複数の断層線が互いに近づく方向に向かって枝 分かれして対置する場合（図 1-B-3）は，破壊は それぞれの断層線の分岐方向へ伝播する。このた め, それぞれの断層線は別々の破壊開始点を持つ 独立した起震断層となると予測されることから， このような分岐形状の発達は, 断層のセグメント 境界を推定する指標となろう。

このような断層分岐と破壊伝播の関係を検証す るために, 震央位置が明らかになっている最近の 地震断層について, 断層の分岐方向と破壊伝播方 向について検討する。縦ずれ断層は横ずれ断層と 比較して複雑な断層線を構成することが多く, 断 層面が低角度である場合, 地表では断層線が湾曲 する例が多いため, 地表の断層の分岐形態は横ず れ断層のように単純明解ではない。ここでは地震 断層のうち, 断層面が鉛直に近いことから比較的 忠実に地下の震源断層の形態を表現していると考 えられる横ずれ断層について, 最近の歴史時代に 発生した大地震を例に検討する。

\section{III. 地震断層の分岐と破壊伝播}

\section{1) 1995 年サハリン北部地震}

1995 年 5 月 28 日午前 1 時 3 分 (日本時間では 27 日 23 時 3 分）に発生したサハリン北部地震で は, 北北東-南南西方向の右横ずれ活断層が活動 し, 長さ約 $35 \mathrm{~km}$ にわたって地震断層が出現した (嶋本ほか, 1996)。観測網の不備から決定精度は 良くないが, 本震の震央位置は, ハーバード大学 (Dziewonski et al., 1996) によれば北緯 52.51。, 東経 $142.87^{\circ}$, 菊地（1996）によれば北緯 $52.64^{\circ}$, 東経 $142.83^{\circ}$ と推定されており，いずれも地震断 層の南方にあり, 菊地（1996）の推定震央は断層 南端と $\pm 5 \mathrm{~km}$ の範囲内で一致している。これら のことから, 断層破壊は南端付近から一方向に進 行したと推定される。 


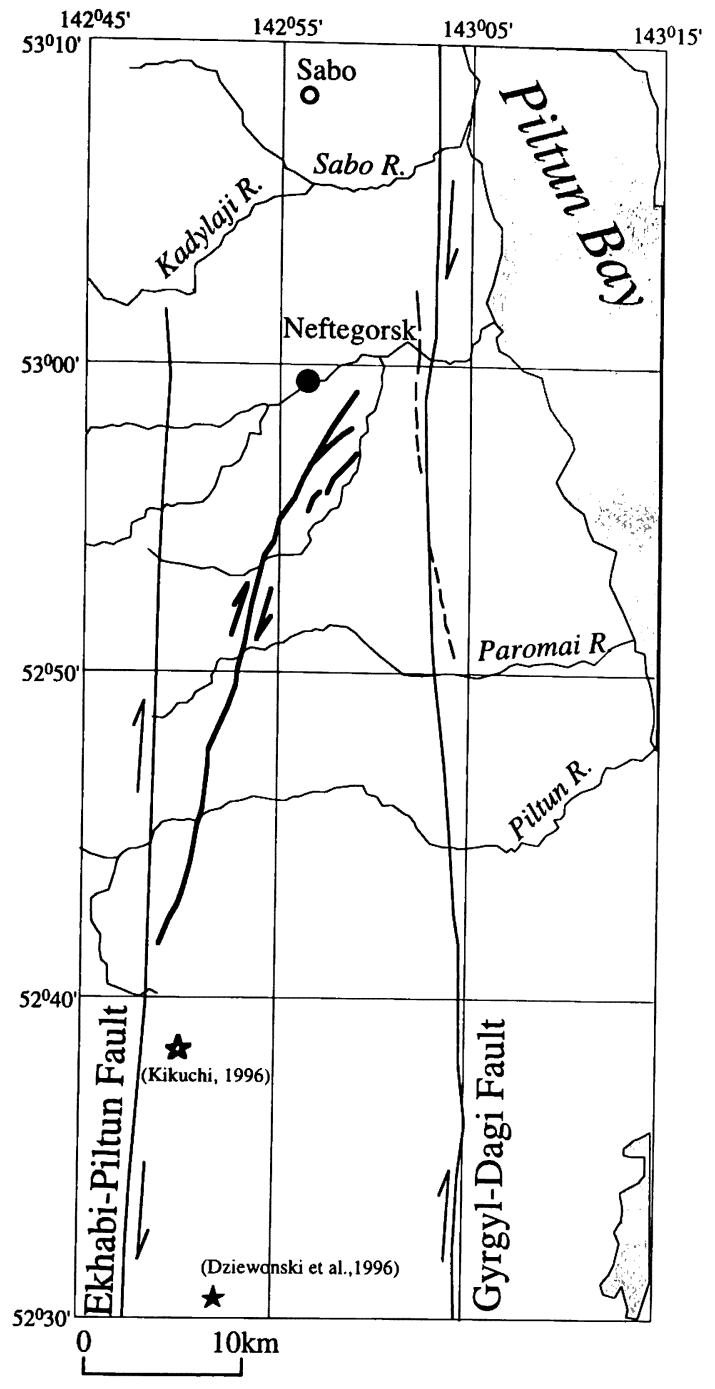

図2 1995 年サハリン北部地震の地震断層の分岐 形態と震央.

Kozhurin and Strel'tsov（1995）を改変。太線は 地震断層, 細線は活断層.

星印は震央. Dziewonski et al. (1996) と菊地 (1996) による.

Fig. 2 Branching of the surface fault-ruptures associated with the 1995 Northern Sakhalin earthquake modified after Kozhurin and Strel'tsov (1995).

Stars are epicenters located by Dziewonski et al. (1996) and Kikuchi (1996).
地震断層沿いでは地震の規模 $(M w=7.0)$ に比 して大きな変位が確認され，その最大值は右横ず れ $8.1 \mathrm{~m}$, 平均 $3.8 \mathrm{~m}$ であった（嶋本ほか, 1996)。 変位の最大值は断層中央部のやや北奇りに位置し, その付近では断層沿いにおいて地震動に伴って倒 潰したと判断される樹木が多数発見された。その 倒潰方向は断層に直交し, 東南東向きに倒れてお り，南方から断層破壊が伝播した際のS 波によっ て倒潰したものと判断された。

地震断層のトレースは直線的であるが，北部の 約 $5 \mathrm{~km}$ の範囲では北東走向に向かって 3 本に分 岐しており（Rogozhin，1995; Kozhurin and Strel'tsov, 1995)，その分岐方向は断層破壊が南 から北へ伝播したことと調和的である(図 2)。なお， 断層破壊の末端部にあたる断層北端部から 2 3 $\mathrm{km}$ に近接していたネフチェゴルスクは壊滅し， 住民約 3 千人のうち，1,989 人の犠牲者が出た。

\section{2） 1995 年兵庫県南部地震}

1995 年 1 月 17 日に発生した兵庫県南部地震で は, 淡路島北西岸の野島断層が再活動し, 長さ約

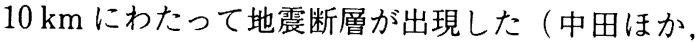
1995 ほか)。本州側では地表に明瞭な断層変位を 伴う地震断層は出現しなかったが, 帯状の被害域 の広がりや余震域の分布から, 地下で東北東方向 の断層が活動したことは確かである。淡路島に出 現した地震断層では, 震央から約 $7 \mathrm{~km}$ 南の梨本 において南に分岐する副次的な断層が認められる (図 3)。この断層の分岐方向は断層の破壊が北か ら南へ伝播したことを示している。地震の震源は 淡路島の北端部に近い明石海峡の地下 $15 \mathrm{~km}$ とさ れており，断層の破壊はそこから東北東と南西の 双方向に伝播したこと（少なくとも淡路島におい ては）と一致する。淡路島では断層破壊の進行方 向にあたっていた断層末端やさらに南部の地域で 地震被害が大きかった。

一方, 地震断層が地表に現われなかった神戸付 近では，巨視的にみれば，この地震の際に地下で 動いたとされる六甲断層系の活断層が北東に向かっ て分岐しており，破壊が南西から東に進んだこと を示唆する。しかし，後述するように，神戸市街 北縁の活断層の分岐形態は必ずしもこれを支持す 

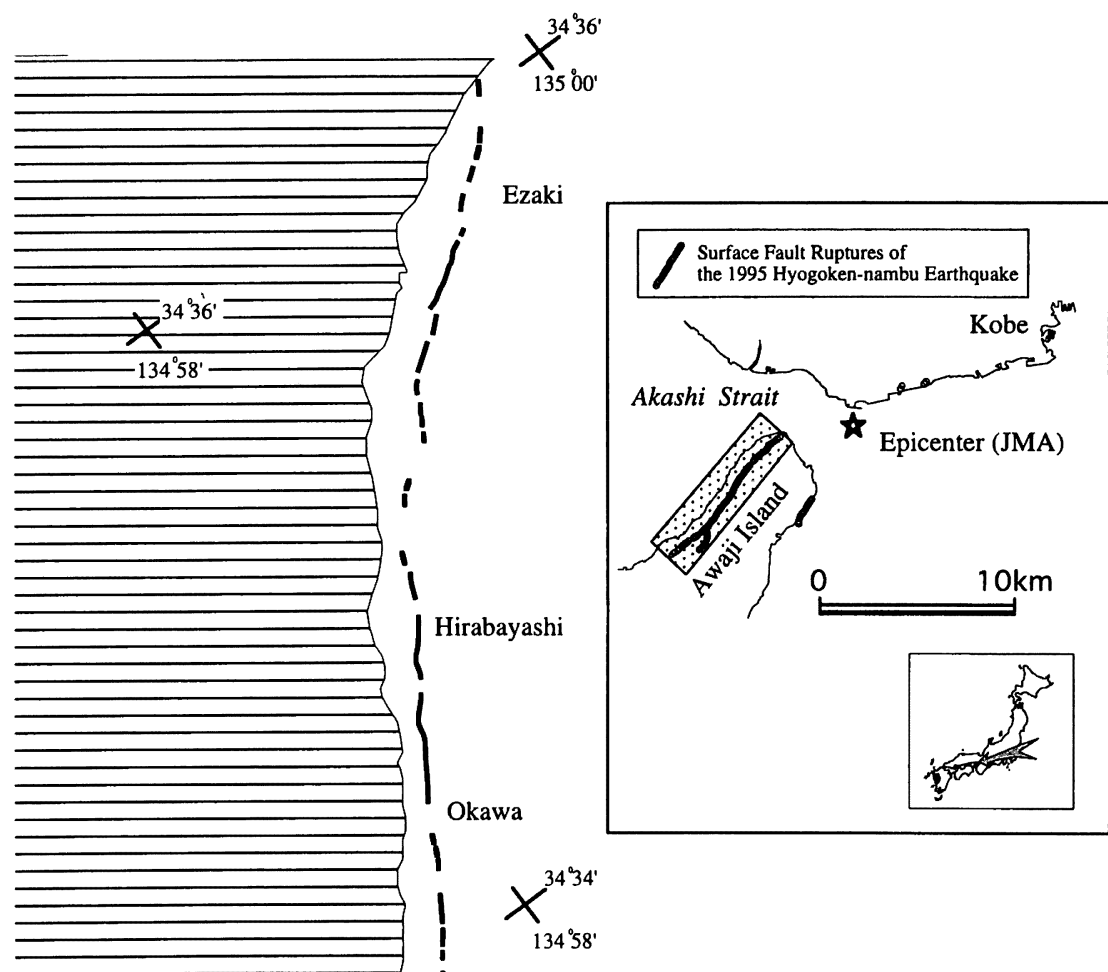

$$
4^{\prime}
$$

Todoroki

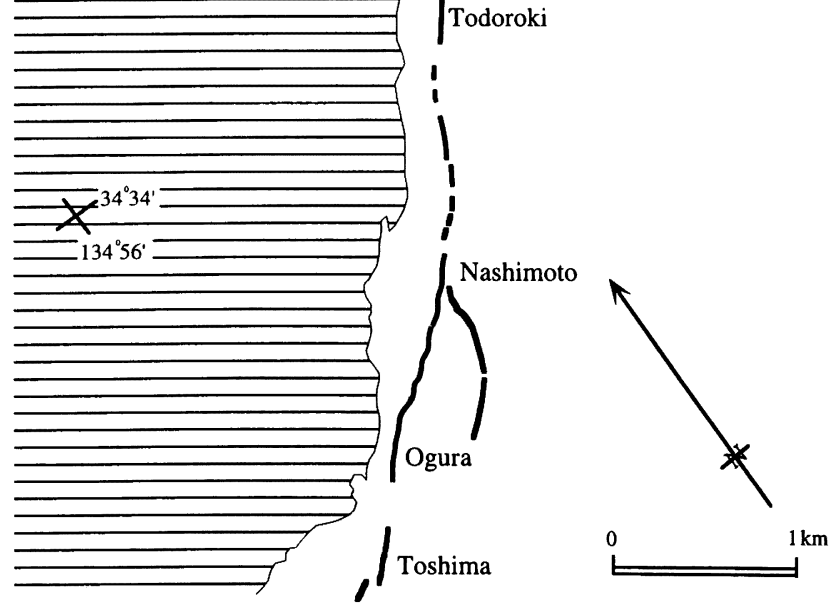

図 31995 年兵庫県南部地震の野島断層に沿う地震断層の分岐. 中田ほか（1995）を改変。

Fig. 3 Branching of the surface fault ruptures associated with the 1995 Hyogokennambu earthquake modified after Nakata et al. (1995).

るものではない。

3） 1992 年ランダース地震

アメリカ・カリフォルニア州の南東部で 1992
年に発生したランダース地震では, 右にステップ する雁行状の地震断層が北北東一南南西方向の断 層系をなすようにして出現した（図 4)。本震の断 


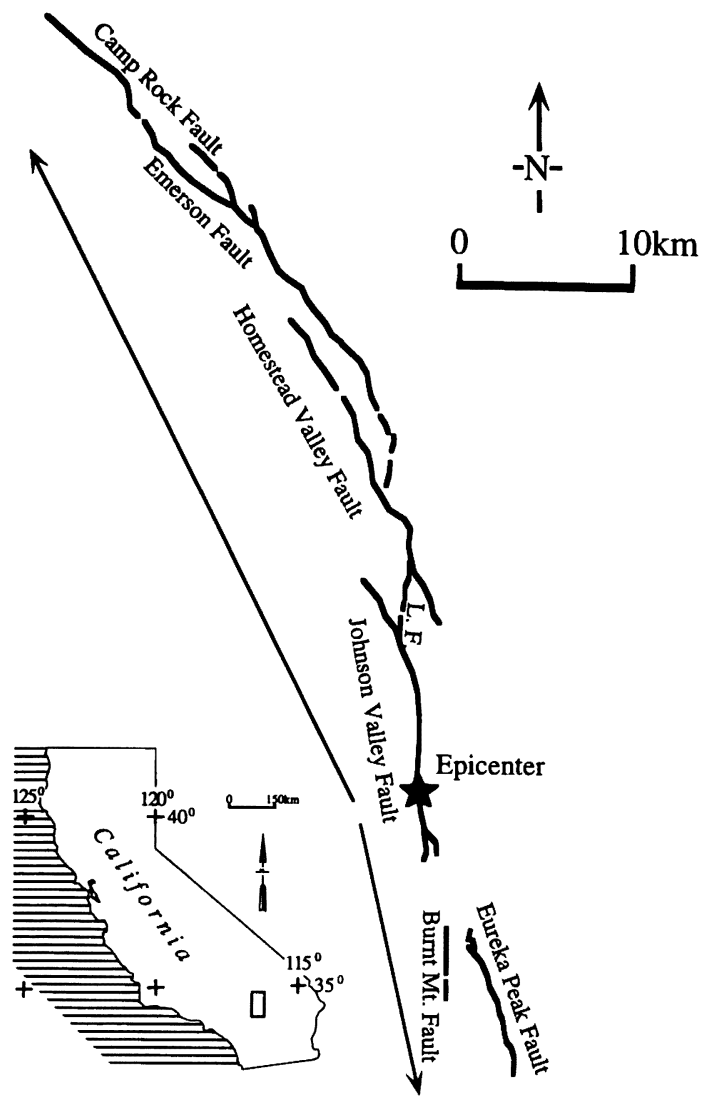

図 41992 年ランダース地震の地震断層の分岐と 破壊伝播。

地震断層はSieh（1996）による。L，F．は Lnders 断層.

Fig. 4 Branching of the surface fault ruptures associated with the 1992 Landers earthquake modified after Sieh (1996).

L. F. : Landers Fault

層破壊は, Johnson Valley 断層の南端付近から 北あるいは北西に一方向に既存の活断層に沿って 伝播し, Landers 断層, Homestead Valley 断層, Emerson 断層, Camp Rock 断層が出現している。 地震断層の平面形状から, 断層の破壊は北に向かっ て分岐しながら既存の活断層を乗り換えるように 伝播したと推定することができる。Johnson Valley 断層の平面形を詳細に観察すると，震央の 南にあたる断層の末端部が南に分岐していること がわかる。本震の開始後, 約 30 秒後で Johnson Valley 断層のずれが終わり，この 20 秒後に
Eureka Peak 断層と Burnt Mountain 断層が地 震断層として出現したとされている（Sieh，1996）。 これらの地震断層は Johnson Valley 断層の分岐 を延長した位置に, 南に開く「八」の形状をして 発達している。このような断層の分岐形態は, 地 震断層の南への破壊伝播に一致していると解釈す ることができる。

\section{4） 1990 年フィリピン・ルソン地震}

1990 年 7 月 16 日に発生したルソン地震 $\left(M_{S}=7.8\right)$ は, ルソン断層系北部の活断層の再活 動によるもので，ルソン島北部に延長 $125 \mathrm{~km} に$ も及ぶ長大な地震断層が現われた（Nakata et $a l ., 1996)$ 。地震断層には南から約 3 分の 1 の地 点の Rizal の北に最大のギャップ（圧縮性バリア） が存在しており，これょり北では断層の走向は北 北西-南南東であるのに対し, 南では北西-南東方 向に延びる。地震断層の詳細な分岐形態をみると， Rizal 市街地の南西端付近で主断層から北に分岐 する副断層が認められ（図 5), 破壊伝播は最大の 圧縮バリアより南の地点から北に向かって進行し たと推定される。USGSの決定したこの地震の震 央は Rizal の南西約 $5 \mathrm{~km}$ の Macapsing 付近に位 置し, Macapsing のすぐ北では短い副次的な断層 が北ないし北東に向かって主断層から分岐してい ることからも，この推定は妥当であると考えられ る。これに対し, Macapsing の南約 $1 \mathrm{~km} に は$ 北 西一南東に延びる主断層から短い断層群が南に分 岐している。これらのことから，震源断層は Macapsing 付近で割れ始め, その後破壊は南北双 方向に伝播したと考えられる (Nakata et al., 1996)。

5） 1979 年インペリアルバレー地震

Imperial 断層は, カリフォルニア州からメキシ コにかけて発達する長さ約 $60 \mathrm{~km}$ の活断層である。 この断層の北半部の約 $35 \mathrm{~km}$ が 1979 年に活動し, $M_{L}=6.6$ のインペリアルバレー地震が発生した。こ の地震の震央は地震断層の南のメキシコ領内に位 置し，断層破壊は南から北に向かって伝播したと 考えられる（Sibson，1986）。地震に伴って地表 に出現した断層は北に向かって分岐し, Brawley 断層と呼ばれる長さ十数キロメートルの副断層を 


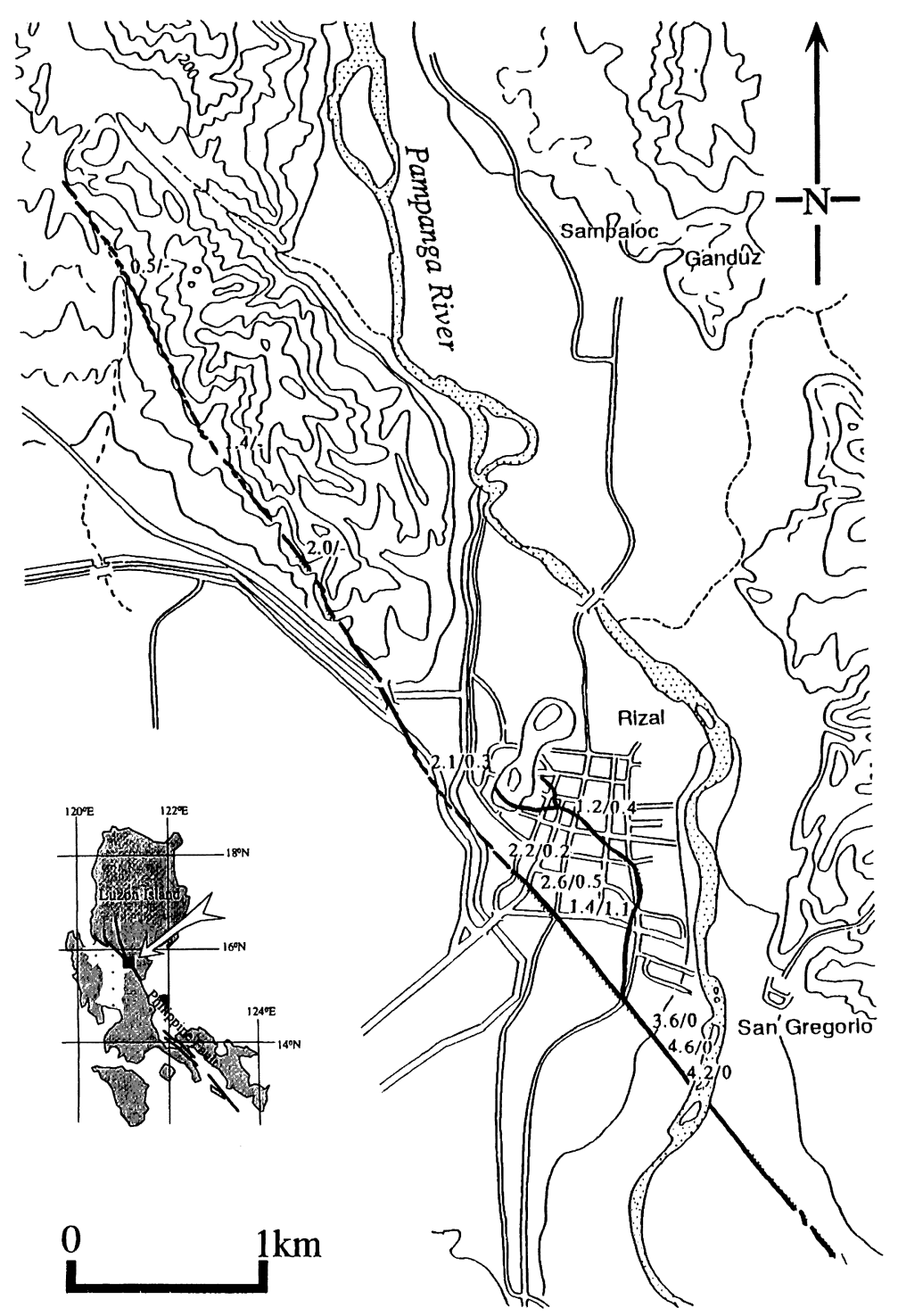

図 51990 年フィリピン・ルソン地震の地震断層中央部リサール周辺の分岐形態. 断層線は Nakata et al. (1996). 図の位置は図 11 参照.

Fig. 5 Branching of the surface fault-ruptures associated with the 1990 Luzon earthquake near Rizal modified after Nakata et al. (1996). Location of the figure is shown in Fig. 11.

生じた (図 6$)$ 。地震後の余震活動は地震断層の北 部に集中し，最大余震に伴う東北東-西南西の短 い地震断層が北端部から約 $10 \mathrm{~km}$ 北の余震域の端 に出現した。この地震断層の分岐形態は単純明瞭 であり，北への一方向の破壊伝播との対応関係を
明解に示している。

\section{6） 1930 年北伊豆地震}

1930 年 11 月 26 日に発生した北伊豆地震 $(M$ 7.3）は，伊豆半島の北部を南北に走る北伊豆断 層系を震源とする地震で, 雁行する多くの断層線 


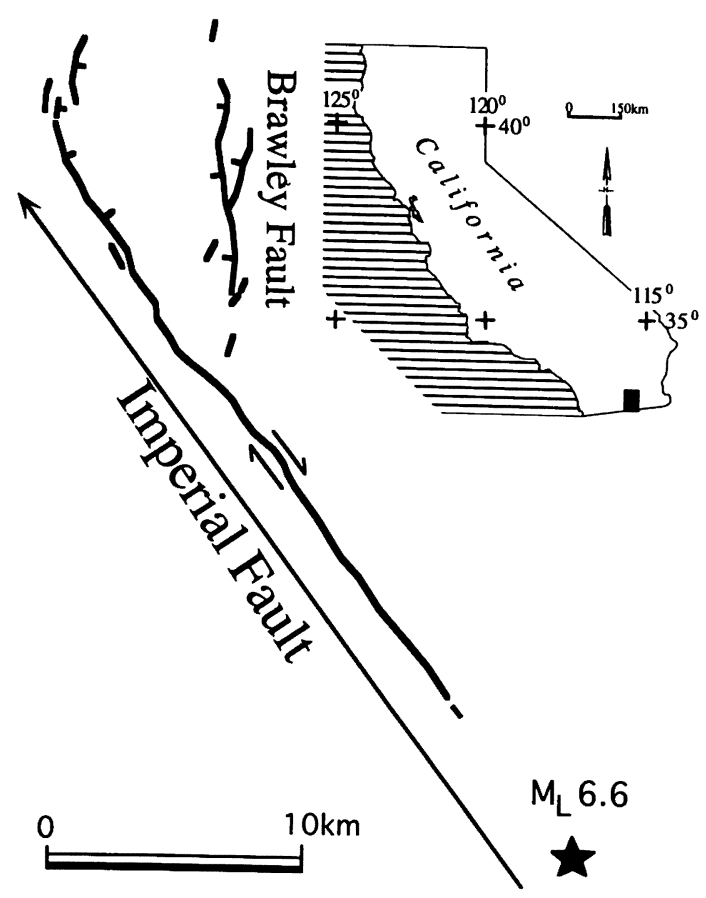

図 61979 年インペリアルバレー地震の地震断層 の地震断層の分岐と破壊伝播.

Sibson（1986）を改変.

Fig. 6 Branching of the surface fault ruptures and rupture propagation of the 1979 Imperial Valley earthquake modified after Sibson (1986).

から構成される地震断層が出現した。この地震断 層では, 北部の箱根町断層と茨ヶ平断層が南の主 断層から北に向かって分岐している。また，浮橋 中央断層と浮橋西方断層の配置は南に断層が分岐 する様子を示している(図 7)。

Abe（1978）は, この地震の最初の破壊は丹那 断層の北端部で起こり, 北から南へ破壊が伝播し, 次に第 2 の破壊が丹那断層の南端部にあり, 破壊 はさらに南方に進んだと推定した。一方，佃 （1991）は, 吉田・浜田（1986）の本震の再決定 結果にしたがって, 韮山峠付近のバリアで最初の 破壊が起こり，その南北双方向に破壊が進行した と考えた。しかし，韮山峠付近のバリアに近い丹 那断層の南端部は, 南に分岐する小規模な断層線 が認められ，これを重視するならば丹那断層は北 から南に破壊したと考えることができる。したがっ
て, 分岐形状からは地震断層の破壊開始点は芦, 湖南方のバリアに位置し, 破壊はそこから南北双 方向に伝播したと推定できる。

\section{IV. 活断層の破壊伝播方向の推定}

地震断層は既存の活断層の再活動によって地表 に出現する場合が多く，地震断層が分岐する場合， その分岐形態は活断層線の形態に一致することが 多い。したがって，活断層線に分岐が認められる 場合，その分岐形状をもとに将来の地震の際にど のように断層破壊が伝播するかを推定することが できると考えられる。このような手法をもとに， 大地震を発生する可能性が高いと判定される活断 層について, 破壊の進行方向を的確に予測するこ とができれば, 強振動子測に重要な情報を提供す ることが可能となり, 地震災害の軽減にこの手法 の果たすの意義は極めて大きいといえる。

しかしながら，従来の活断層図（例えば，活断 層研究会, 1991）は, 活断層の位置の概要を示す ことに主眼がおかれており，断層線の分岐形態に 特に留意して作成されたものとは言い難い。その ため, 既存の活断層図に基ついて, 具体的に破壊 伝播方向や開始点を推定することには限界がある。 将来, 断層線の分岐に注目した活断層図が作られ れば，上述のような震源過程を推定することがで き, 地震被害の軽減に資する重要なデー夕を提供 することになろう。

ここでは，いくつかの横ずれ型と縦ずれ型の活 断層を例に断層線の分岐形態を検討し, 破壊伝播 方向を推定する。

\section{A）横ずれ活断層の検討}

1. 京阪神地域の活断層群

『日本の活断層』の京都及大阪図幅中の有馬-高 柣構造線活断層系は, 大阪平野の北縁部から六甲 山地の北部にかけて東西方向に延びている（活断 層研究会, 1991)。最近の空中写真判読結果によ ると（中田ほか，1996），この活断層系は直線的 な主断層のほぼ中央にあたる池田市付近を境に， 東半部では五月山断層や箕面断層のように北東に, あるいは坊島断層のように南東に分岐する傾向が 認められる（図 8)。また, 西半部では名塩断層や 


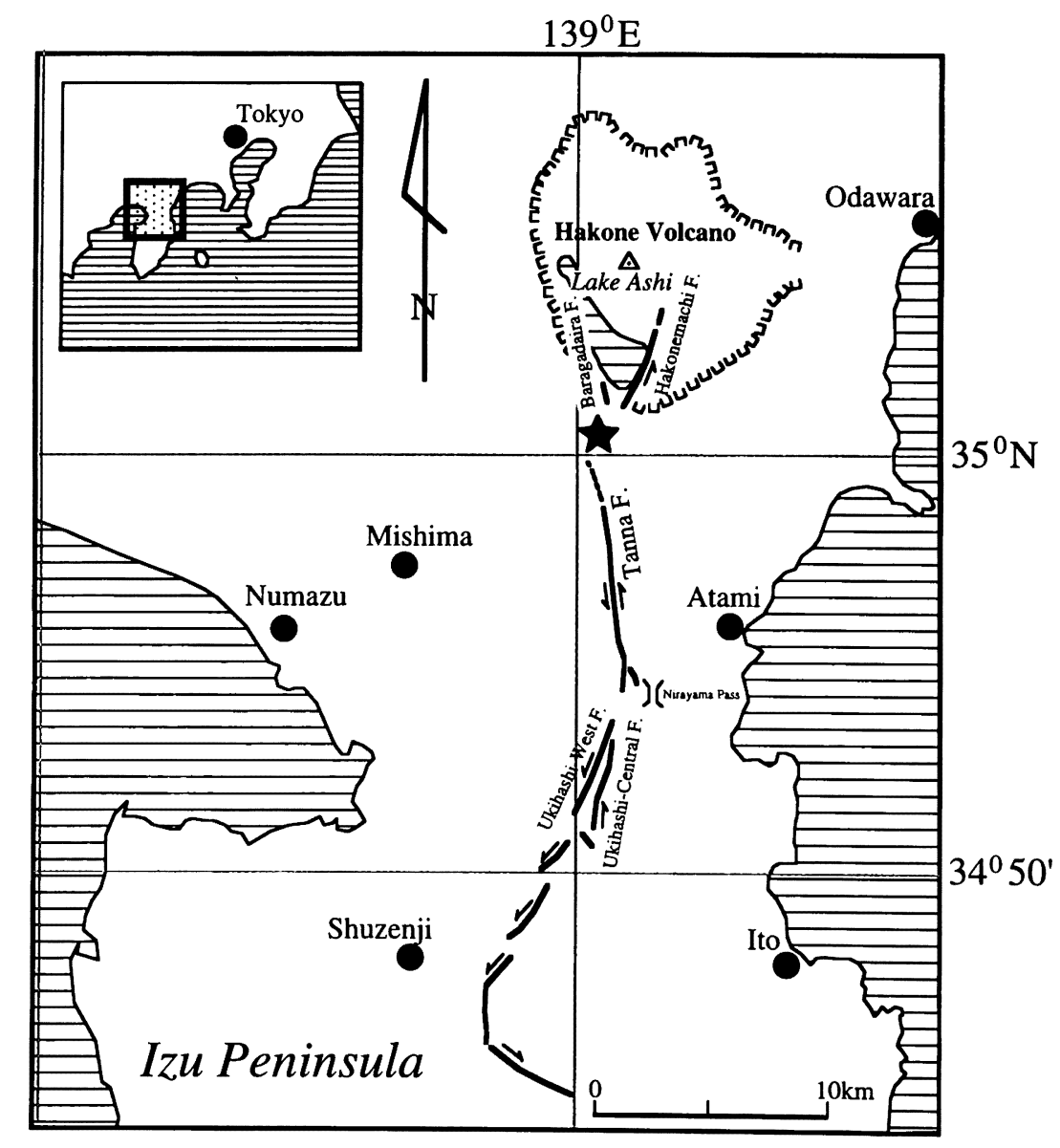

図 71930 年北伊豆地震の地震断層の地震断層と震央（星印）. 佃（1991）を改変.

Fig. 7 The surface fault ruptures and epicenter of the 1930 Kita-Izu earthquake modified after Tsukuda (1991).

star : epicenter

有野断層のように北西に，あるいは六甲断層や湯 槽断層のように南西に分岐する特徵がみられる。 したがって、この活断層系が再活動する場合，断 層破壊は池田市付近から双方向に東西に伝播する と推定される。1596 年の慶長伏見地震はこの活断 層系が発生源と考えられるが, 東端地域に地震被 害が大きかったとされることは，上述の推定と調 和的である。

一方, 六甲山地南麓の神戸市街北縁に発達する 活断層系では, 諏訪山断層は東では五助橋断層, 甲陽断層などが北東に分岐し，西では会下山断層
は南西に分岐する（渡辺ほか, 1996）。これは, 神戸市街北縁の活断層が双方向に破壊伝播するこ とを暗示しており，1995 年兵庫県南部地震の際に, この断層が北西へ破壊伝播したとする説を必ずし も支持するものではない。したがって，いわゆる 「災害の帯」内に存在する東西性の撓曲崖の地下 にこの地震の発生源となった活断層が伏在すると する考え（嶋本ほか, 1995）を再評価する余地が あることを示しているといえる。この撓曲崖の地 下にあると推定される逆断層は，須磨付近で六甲 山地南縁の活断層から西に向かって分岐している 


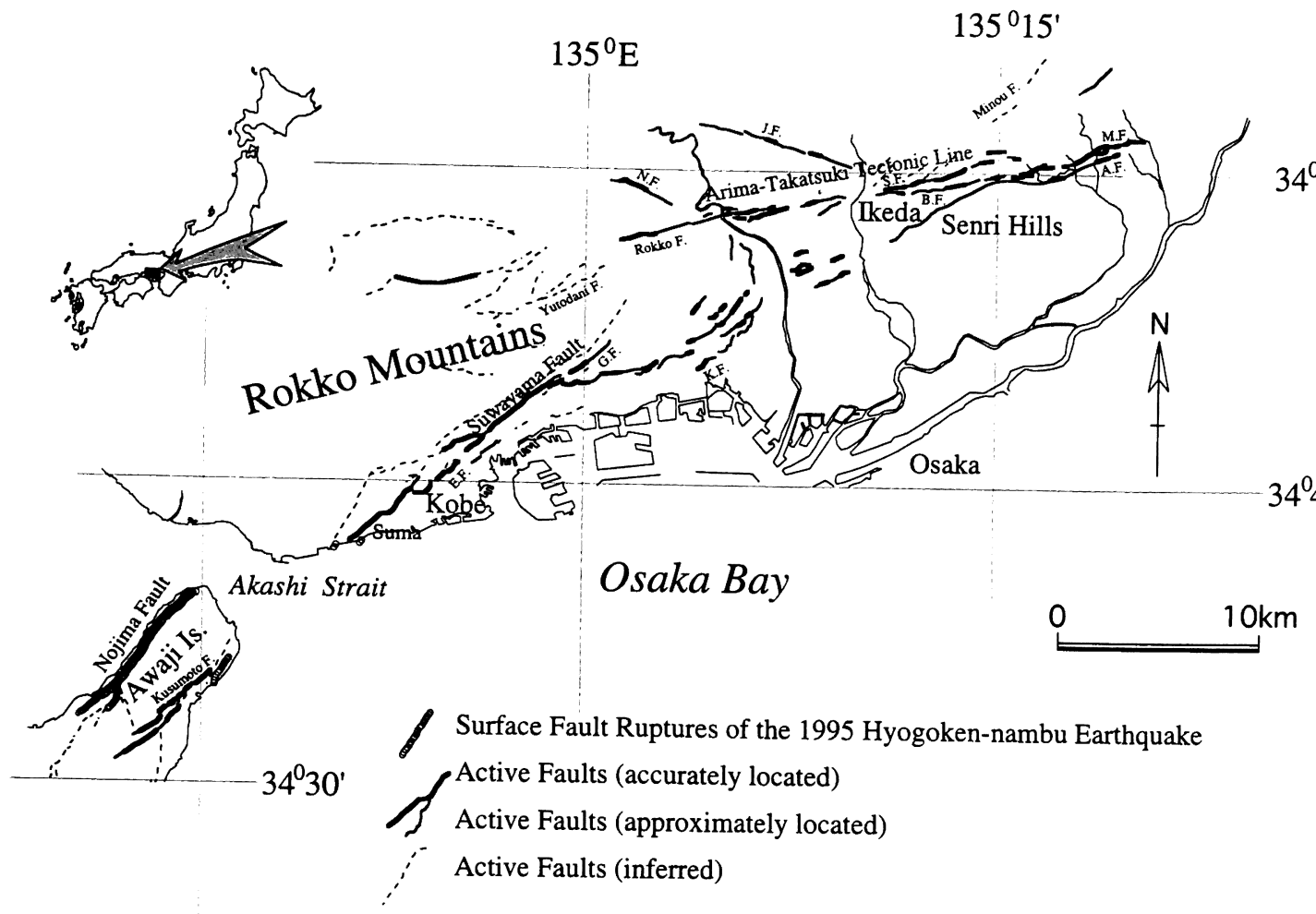

$134^{\circ} 45^{\prime} \quad$ M.F.Maue Fault A.F.:Ai Fault S.F.:Satsukigaoka Fault B.F.:Boujima Fault J J.F.:Jumantsuji Fault N.F.:Najio Fault

図 8 京阪神地域の活断層と 1995 年兵庫県南部地震断層.

断層線は中田ほか(1996)，渡辺ほか(1996) などによる。

Fig. 8 Active faults in Kobe-Osaka area and the surface fault-ruptures and epicenter of the 1995 Hyogoken-nambu earthquake.

Fault traces are after Nakata et al. (1996) and Watanabe et al. (1996).

と推定され、このような分岐の方向は兵庫県南部 地震の破壊伝播の方向と一致する。

淡路島では, 野島断層や楠本断層は南部で南に 向かって分岐している（図 8)。これは，これらの 活断層では南に向かって破壊が伝播することを示 唆しているが,このことは 1995 年兵庫県南部地 震の際に, 野島断層に沿って断層伝播が北から南 に進行したことによって立証されたといえる。

2. カリフォルニア州の活断層系

カリフォルニア州は, San Andreas 断層をはじ め多数の横ずれ断層が発達している地域である。 これらの活断層には，断層線の分岐から破壊伝播 方向を推定できるものが多い。巨視的にみれば,
San Andreas 断層から分岐する活断層は, 北部で は北方に，南部では南方に分岐する傾向が認めら れる。これらの形態から, San Andreas 断層の破 壊は北半部では北に向かって伝播し，南半部では 南に向かって伝播すると推定される。直線的な形 状を持つSan Andreas 断層の北部で発生した 1906 年のサンフランシスコ地震では, 震央の位置 から断層の破壊伝播は双方向であったと推定され るが，主たる破壊は北に向かって伝播したと考え られている (Ellseworth，1990)。一方，1857 年 にSan Andreas 断層が活動して発生したホート テホン地震では, 震央は Big Bend と呼ばれる大 屈曲の北端に位置し, 破壊は南東に向かって伝播 


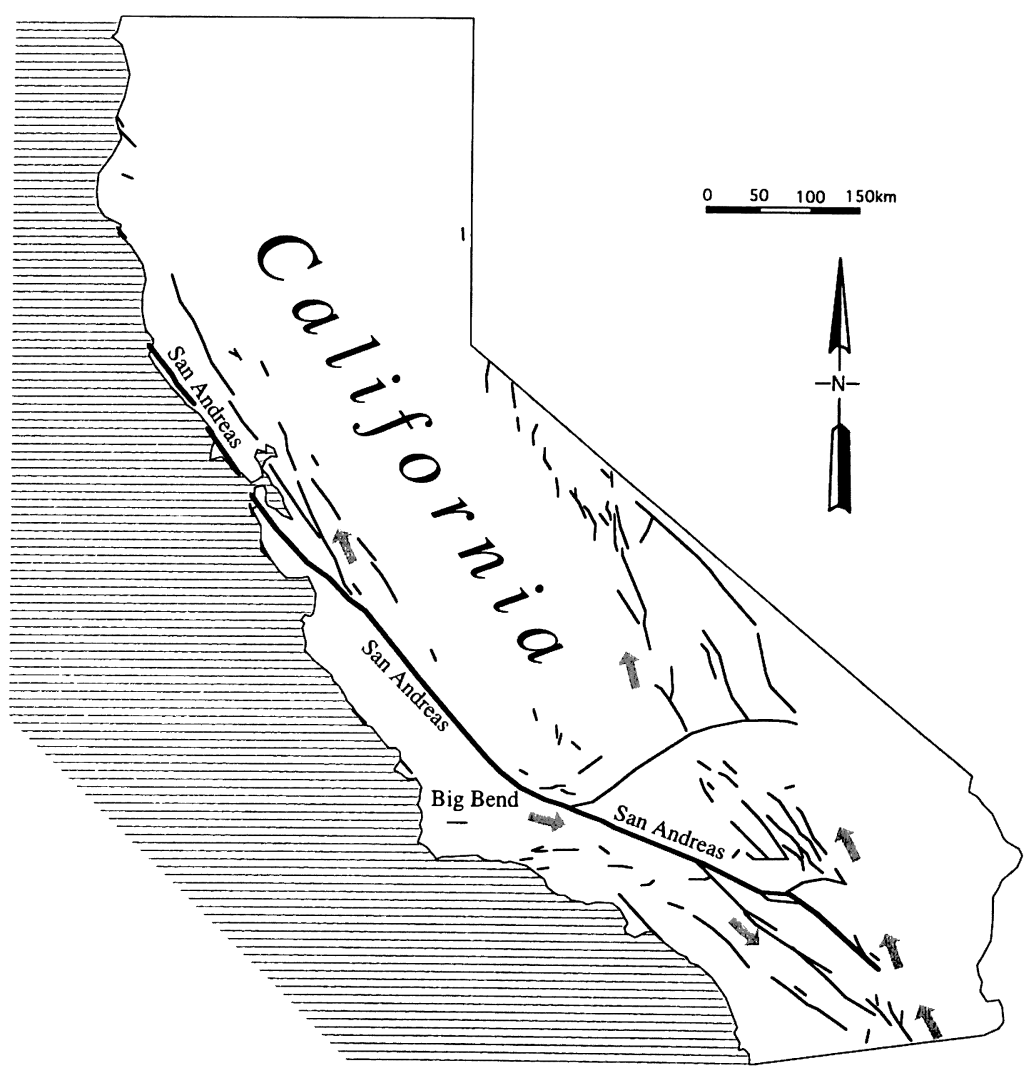

図 9 カリフォルニア州の活断層系.

断層線は Hart（1990）による. 矢印は破壊伝播の推定方向.

Fig. 9 Active faults in California.

Fault traces are after Hart (1990).

Arrows indicate directions of inferred rupture propagation.

したと考えられており（Ellseworth，1990）こ れは南部の南への断層分岐に対応している。歴史 時代に大地震を発生させた断層線については, 事 例ごとに分岐形態をさらに詳細に検討し破壊伝播 について具体的に議論する必要がある（図 9)。

San Andreas 断層以外の活断層で, 断層線の分 岐から破壊伝播の方向を推定できるものも少なく ない（図 10）。上述の Landers 地震に伴って生じ た地震断層の北東には, Calico 断層, West Calico 断層, Hidalgo 断層からなる約 $70 \mathrm{~km}$ の活断 層系がある。この断層系では, West Calico 断層 の北端部で断層線が北に向かって分岐するのが認 められ，中央部では副次的断層が南東に分岐する。 また,この断層の南端でも南東の Hidalgo 断層へ
ステップするところで南に断層線が南東に分岐す る。したがって，このような断層分岐形状から， この断層系は West Calico 断層の中央部に認めら れる断層のステップ付近で破壊が始まり，北西と 南東に双方向に破壊が伝播したと推定することが できる。

また, Landers 地震断層の西には, 東西方向に 延びる逆断層性の前縁断層帯 (Frontal Fault Zone）から，北西の方向にLenwood 断層や Helendare 断層が北西に向かって分岐している。 Lenwood 断層では，その北端部でも北西への分 岐形状が認められ，断層の破壊伝播が南から北に 向かって起こることを暗示している。

3. フィリピン断層北部活断層系 


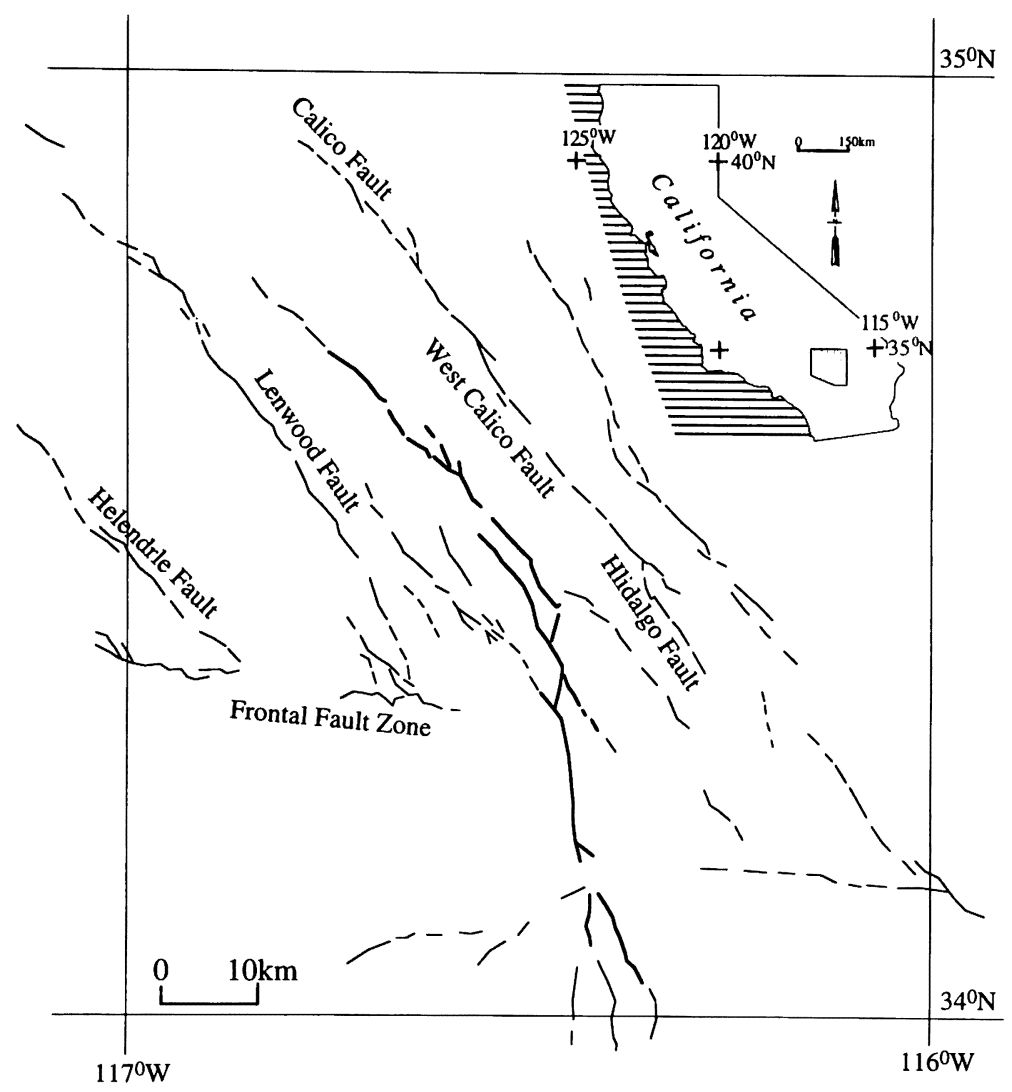

図 10 カリフォルニア州南東部の活断層系.

断層線は Jennings（1994）より抽出.太線はランダース地震の地震断層.

Fig. 10 Active faults in southeastern California.

Fault traces are extracted from Jennings (1994).

Thick lines are the surface ruptures the 1992 Landers earthquake.

上述した 1990 年ルソン地震の震源域にあたる ルソン島北部には,この地震を発生させた Digdig 断層の他に, 北東の山地と南西の中央低地の境界 に沿って北西-南東方向のSan Jose 断層, San Manuel 断層， Gabaldon断層が発達する (Nakata et al., 1976; 平野ほか, 1986)。

このうち San Jose 断層は, Rizal の北西で Digdig 断層から北西に分岐するように断層線が 発達し, San Manuel 断層はSan Jose 断層の北 部でさらに北西に分岐する（図 11）。一方， Gabaldon 断層は Bongaban の北で Digdig 断層か ら南西方向に分岐する。このような断層分岐形態 から, San Manuel 断層と San Jose 断層の破壊
はそれぞれの断層の南端部付近から北に向かって 伝播すると推定される。また, Gabaldon 断層は, その北端部から南に向かって破壊が伝播すると考 えられる。

\section{B）縦ずれ活断層系の検討}

上述したように, 縦ずれ断層は複雑な断層線を 構成することが多く, 地表では断層線は湾曲し, 地表の断層の分岐形態は必ずしも明解ではないが, ヒマラヤ山脈の前縁帯に位置するダージリン・ヒ マラヤ南縁では断層線の分岐がはっきりしており， 断層の破壊伝播方向を検討できる。

ヒマラヤ前縁部は, インドプレートとユーラシ アプレートの衝突境界にあたり，大規模な逆断 


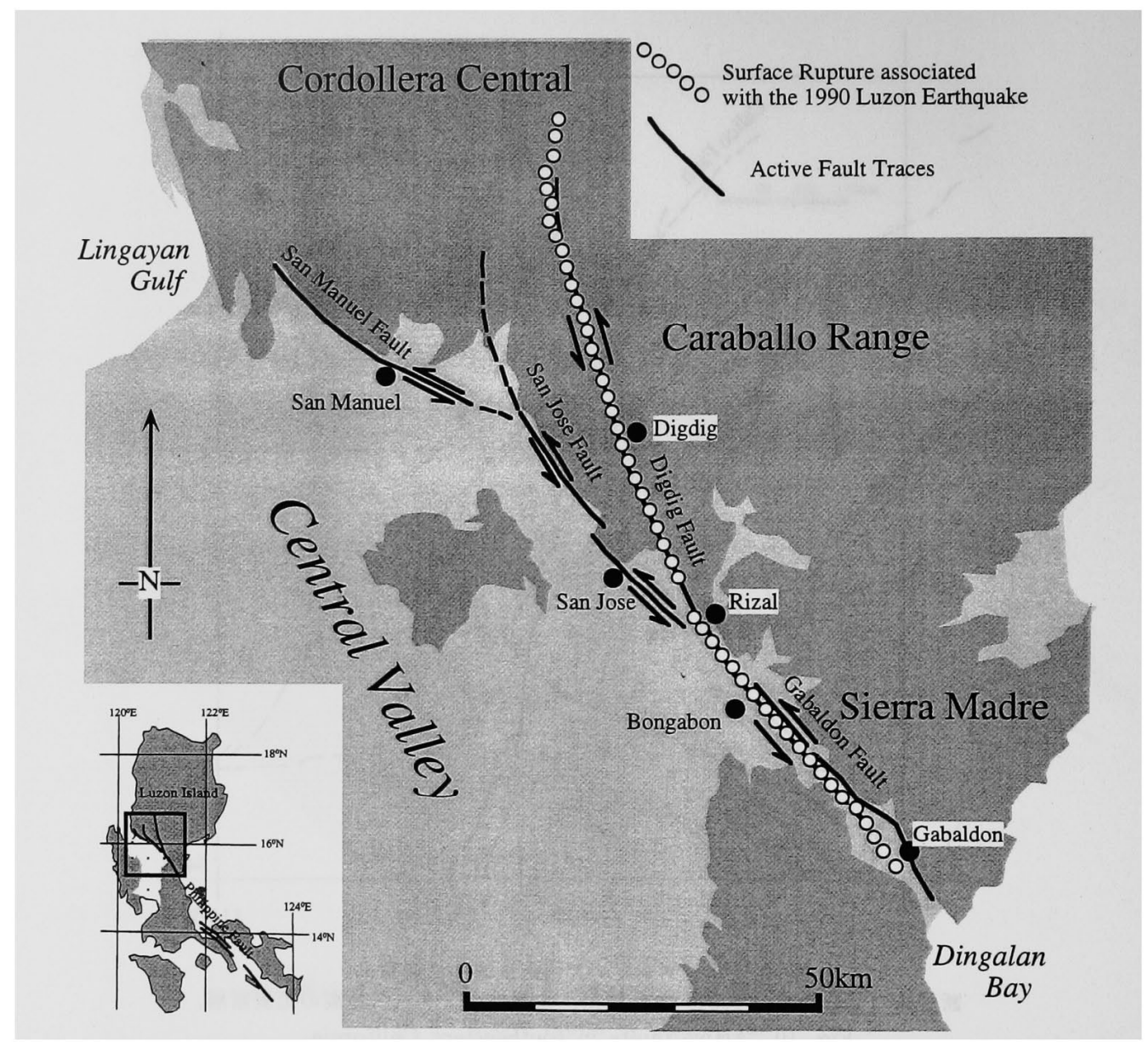

図 11 ルソン島北部のフィリピン断層活断層系と 1990 年ルソン地震の地震断層. 断層線は Nakata et al. (1996) による.

Fig. 11 Active faults in the northern Luzon Island and the surface fault ruptures of the 1990 Luzon earthquake.

Fault traces are after Nakata et al. (1996).

層が発達する。2,500 $\mathrm{km}$ にも及ぶ山脈の南麓部に は，第四紀後期の断層活動を示す断層地形が豊富 に存在する（Nakata, 1972）。

このうち東部のダージリン・ヒマラヤのティス 夕河の東の山麓部には, 主境界断層 $(\mathrm{MBF})$ と 前縁断層（HFF）に関連する活断層は扇状地や河 岸段丘を断ち切って断層崖を発達させる（中田， 1982)。この地域では, 主境界断層に沿って発達 する活断層は, 西のチェル川の谷口周辺ではほぼ 東西に延びる一本の断層線として認められるが, 東部のネオラ川西岸から南東に湾曲する断層線と
北東にステップする断層線に分岐している（図 12）。 一方, 前縁断層はシワリク丘陵南縁の延長線上に 出現し西部では撓曲崖をなしているが, チャルサ （Chalsa）付近で一本の明確な断層線をなす。こ の断層線はさらに東では再び撓曲崖となって不明 瞭になる。したがって, この地域の活断層に沿っ ては断層破壊は西から東に伝播すると推定するこ とができる。

このほか, ネパールの南東部の活断層において も, 活断層線は東に向かって分岐する形態が認め られ、ここでも東に向かっての断層破壊伝播が推 


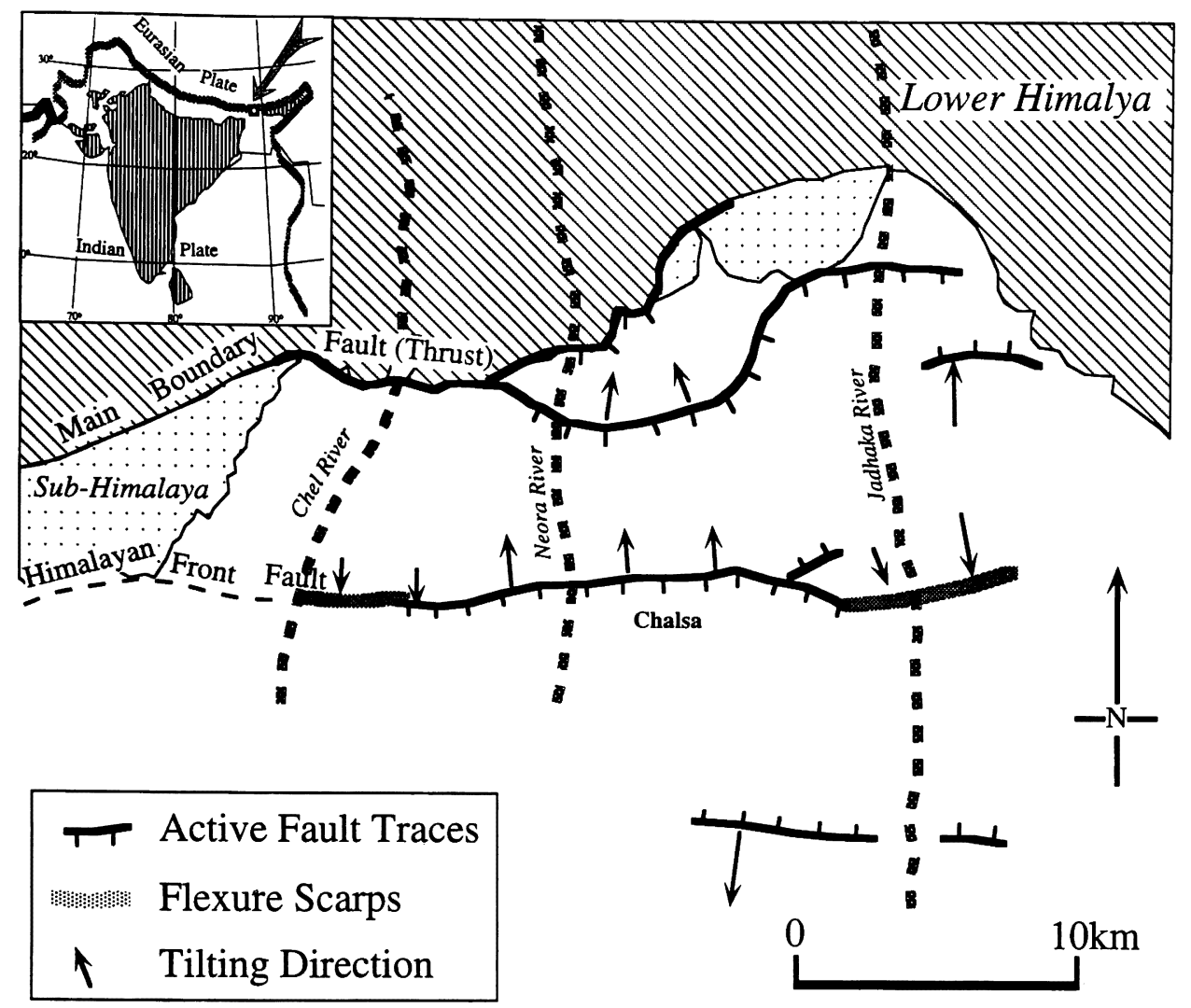

図 12 ダージリン・ヒマラヤ前縁の活断層の分岐形態. 断層線はNakata（1972）による。

Fig. 12 Active faults in the foot-hills of the Darjeeling Himalaya. Fault traces are extracted from Nakata (1972).

定される。

\section{V. 断層分岐形態とバリア形状に基づく破壊} 開始点の検討

これまで例示した枝分かれする断層線では，そ の分岐形態をもとに破壊伝播方向を推定し，破壊 は伝播方向と反対側にあたる断層線の端から始ま ると予測した。さらにこれに加え，幾何学的形態 から圧縮性バリアの位置を特定できれば，破壊開 始点をより具体的に推定できる。このように，断 層分岐形態とバリア形状に基づいて破壊開始点を 推定するために，左横ずれ断層を例に次のような モデルを提示する（図 13）。

断層線が一方向に分岐する単純な例では，破壊
は分岐しない断層線の端から始まると予測するこ とができる（図 13-A-1）。複数の直線状の断層線 が破壊開始側を構成する場合には，断層線が屈曲 や断層が不連続構造 (ステップ) の形状とずれの センスとの関係から圧縮性バリアの位置はそれぞ れ図 13-A-2 およびA-3のように推定できる。

一方，断層線が双方向に分岐する場合，破壊は それぞれの分岐方向に向かって伝播する。図 13B-1のように比較的単純な分岐断層の組み合わせ の場合は, 破壊は断層線の中間に位置する接合部 から始まると予測される。分岐部の間に断続的な 複数の断層線が発達する場合は, 圧縮バリアがど こにあるかを検討する必要がある。ずれのセンス を考慮すれば, 断層線が屈曲やステップの形状か 

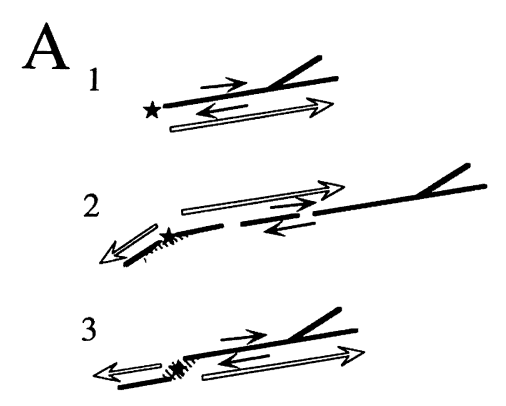

B
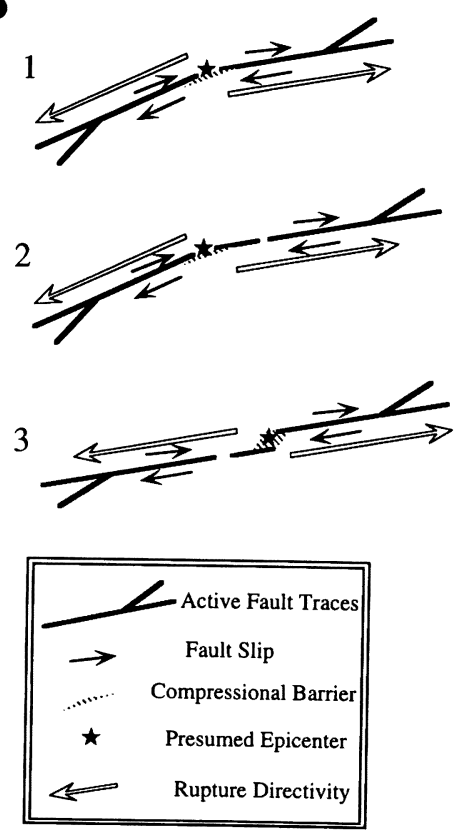

図 13 分岐とジョグを考慮した断層破壊開始点推 定モデル.

Fig. 13 A model for rupture propagation and epicenter from fault trace geometry.

ら図 13-B-2 や B-3のような関係をもとに圧縮バ リアの位置を検討することが可能であろう。

前述した破壊伝播方向が分岐形状から推定可能 な地震断層や活断層について, これらのモデルに 基づいて破壊開始点を具体的に推定してみる。

北伊豆地震で生じた地震断層は, 南北両端で分 岐し破壊が双方向に進行したと推定された（図 7)。 この断層線には, 芦ノ湖南方, 菲山峠付近, 修善
寺南方の 3 カ所にバリアが存在し，そこで断層の 走向が顕著に変化する特徵がある。佃（1991）は, このような断層線の配列から, 芦ノ湖南方と韮山 峠付近のバリアは圧縮性バリア, 修善寺南方のバ リアは引張性バリアであると判断した。したがっ て, 断層分岐形態と圧縮性バリアから推定される 破壊開始点は芦ノ湖南方のバリアとなり, 上述の 推定と矛盾を生じない。これは, モデルのB-2に あたるといえる。

京阪神地域の活断層群のうち, 有馬一高柣構造 線活断層系は断層分岐形態が極めて明瞭なもので, その破壊開始点は池田市付近と推定される（図 8)。 しかし，圧縮性のバリアを識別できる断層線の屈 曲やステップ形状は存在しないため, 上記のモデ ルを適用できない。一方, 六甲山地南部の諏訪山 断層とその東に連なる断層においては, 新神戸駅 付近に断層線の走向の変化が認められ, そこが圧 縮性のバリアと推定されることから，モデルの B-1 が適用されるといえる。

このほか, 『日本の活断層』（活断層研究会, 1991）に基づいて，分岐形態の明確な活断層につ いて断層破壊伝播方向と破壊開始点を推定する予 察的作業を行なった。しかし，いくつかの長大な 断層についてはこの手法が有効であったが，多く の活断層についてはこのような規則性を見いだす ことはできなかった。既存の活断層図でこのよう な分岐形態を見いだすことが困難な理由として， 活断層図が小縮尺であり分岐形態が十分に表現さ れていない可能性があること，活断層を判読する 際にその分岐形態に特に注意を払って作業が行な われて来なかったためなどが考えられる。したがっ て, 今後の活断層の認定作業においては, 断層の 分岐形態にも留意した作業が必要であろう。

\section{VI. おわりに}

断層線の分岐方向と断層破壊伝播の関係を最近 の歴史地震を例に検証し, 横ずれタイプの地震断 層については，筆者らの断層分岐形態と断層破壊 伝播方向には密接な関係があるという予測がほぽ 成り立つことが明らかとなった。しかし，逆断層 性の地震断層については適切な事例を提示するこ 
とができなかった。

地震断層には, 不均質な地質や既存の地質断層 などの影響によって、極めて複雑な形態を呈する ものもある。このような事例で, 断層形態と破壊 伝播方向の関連がどこまで適用できるかを検討す ることが必要である。また, 地震断層には, 多数 の短い引張性の断裂, 断裂が集まった数百メート ルから数キロメートルの断層線など様々なスケー ルの断層線が地表に出現する。このうち，どのス ケール断層線の形状が破壊伝播との関係を反映す るのかを検討することも必要である。

一方, 地表に地震断層が出現する場合, 個々の 断層線は既存の活断層と一致して出現する例が多 い。地震時の断層変位は, 一般に中央部付近で大 きく末端に向かって小さくなる傾向が認められる。 このような変位量分布は活断層の累積変位と極め て類似しており, 断層沿いの変位量分布パターン は変わらないと考えられる。これは, 活断層の地 震時における挙動の長期にわたる不変性を意味し ており, 断層の地表形態と変位量分布からアスペ リテイやバリアの位置が推定できることを示して いる。したがって, 第一次近似的には, 既存の活 断層から将来発生するであろう地震のモーメント の分布を推定することが可能である。このような 現状認識に基づいて，（a）断層の破壊開始点, （b）破壊伝播方向,（c）地点ごとのスリップ量, 等の断層活動の諸元を明らかにすることで, 具体 的な地震「像」を予測することが可能であろう。

今回提示した断層破壊伝播方向の推定モデルは 単純明快であるが，これまで未解決であった（a）， (b) の問題に解答を与える画期的なモデルとなろ う。これによって, 地震被害軽減に関連する強震 動予測に必要な情報が整備されることになり，こ のモデルの果たす役割は極めて大きいと考えられ る。

\section{文献}

Abe, K. (1978): Dislocations, Source Dimensions and Stresses associated with Earthquakes in the Izu Peninsula. J. Phys. Earth., 26, 253-274.

Dziewonski, A.M., Ekstrom, G. and Salganik,
M.P. (1996): Centroid-moment tensor solutions for April-June 1995. Phys. Earth and Planetary Interiors, 96, 1-14.

Ellseworth, W.L. (1990): Earthquake History, 1769-1989. U. S. Geol. Surv. Prof. Pap., 1515, 153-181.

Hart, E.W. (1990): Fault-rupture hazard zones in California. Spec. Publ., 42, California Department of Conservation, Division of Mines and Geology, 26p.

平野信一・中田 高・寒川 旭 (1986): ルソン島中部 におけるフィリピン断層の第四紀後期の断層運動. 地 学雑誌, 95, 71-93.

Jennings, C. (1994): Fault activity map of California and adjacent areas. California Department of Conservation, Division of Mines and Geology.

活断層研究会 (1991): 新編 日本の活断層. 東京大学出 版会, $437 \mathrm{p}$.

菊地正幸 (1996)：遠地実体波によるメカニズム解析。 笠原 稔編: 平成 7 年サハリン北部地震とその被害の 調查研究. 平成 7 年度文部省科学研究費突発災害研究 成果報告書, 北海道大学理学部, 37-43.

King, G.C.P. (1986): Speculations on the geometry of the initiation and termination processes of earthquake rupture and its relation to morphology and geological structure. Pure and Applied Geophysics, 124, 567-586.

小出 仁 (1983): エシュロン断層系の地震地質学的意 義と地震発生機構について. 地学雑誌, 92, 173-192.

Kozhurin, A.I. and Strel'tsov, M.I. (1995): Seismotectonic consequence of the May 28, 1995 northern Sakhalin earthequake. In Russia's Federal System of Seismological Networks and Earthquake Prediction, Information and Analytical Bulletin, Special Issue, "The Neftegorsk Earthquake of May 27 (28), 1995", 93-98.

Nakata, T. (1972): Geomorphic history and tectonic movement of the foot-hills of the Himalayas. Sci. Rep. Tohoku Univ. (7th ser.), 22, 39-177.

中田 高 (1982): ダージリン＝ヒマラヤ山簏の活断層 一プレート境界における地殼変動の一例一。地域一そ の文化と自然，石田 寛退官記念事業会，448-462.

Nakata, T., Sangawa, A. and Hirano, S. (1976): A report on tectonic landform along the Philippine fault zone in the northern Luzon, Philippines. Sci. Rep. Tohoku Univ. (7th ser.), 95, 69-93.

中田高・蓬田 清 - 尾高潤一郎 - 坂本晃章 - 朝日克彦 . 千田 昇 (1995): 1995 年兵庫県南部地震の地震断層. 地学雑誌, 104, 127-142.

Nakata, T., Tsutsumi, H., Punongbayan, R.S., Rimando, R.E., Daligdig, J.A., Daag, A.S. and Besana, G.M. (1996): Surface fault ruptures of the 1990 Luzon earthquake, Philip- 
pines. Special Publication No. 25, Research Center for Regional Geography Hiroshima University, 86p.

中田 高 - 岡田篤正 - 渡辺満久 - 鈴木康弘 (1996): 1 : 25000 都市圈活断層図「大阪西北部」. 国土地理院.

Rogozhin, Y.A. (1995): Neftegorsk earthquake of 27 (28) May, 1995. Geological manifestation and tectonic position of the source. In Russia's Federal System of Seismological Networks and Earthquake Prediction, Information and Analytical Bulletin, Special Issue, "The Neftegorsk Earthquake of May 27(28), 1995", 79-92.

Sibson, R.H. (1986): Rupture interaction with fault jogs. A.G.U. Monogr., 37 (Maurice Ewing 6), 157-167.

Sibson, R.H. (1987): Effect of fault heterogeneity on rupture propagation. Direction in Paleoseismology, USGS Open-filele report, 87 -673, 362-373.

Sieh, K. (1996): The repetition of largeearthquake ruptures. Proc. Nttl. Acad. Sci.,
93, 3764-3771.

嶋本利彦 - 堤 昭人 · 大友幸子 - 川本英子 (1995): 神 戸市・芦屋市・西宮市に扔ける地震被害と推定地震断 層. 陶野郁雄・遠藤邦彦・池田安隆編：1995 年 1 月 17 日兵庫県南部地震 (1995 年 1 月 17 日兵庫県南部地 震調查速報会記録)，日本第四紀研究会， 41-42.

嶋本利彦・渡辺满久・鈴木康弘・A.I.コズーリン・M.I. ストレリーツォフ・E.ロゴージン (1996): 1995 年ネ フチェゴルスク地震の地震断層と被害. 地質学雑誌, 102, 894-907.

寺尾宣三 (1968): 破壊の秘密. 法政大学出版会, $188 \mathrm{p}$. 佃 栄吉 (1990): 地震断層の形態と断層破壊過程. 構 造地質, 35, 103-112.

佃 栄吉 (1991): 断層の幾何学的バリヤと破壊プロセ ス. 地学雑誌, 100, 417-428.

吉田明夫 · 浜田信生 (1986): 1930 年北伊互地震の前震 · 余震の震源再決定. 日本地震学会講演予稿集, 1986, No. 2, 59 .

渡辺满久. 鈴木康弘 - 中田 高 (1996): $1: 25000$ 都市 圈活断層図「神戸」. 国土地理院.

（1997 年 12 月 15 日受付, 1998 年 4 月 20 日受理） 